\title{
Isolation and Structural Characterization of Two New Furanoditerpenes from Pterodon emarginatus (Fabaceae)
}

\author{
Leandra A. R. Oliveira, ${ }^{a}$ Gerlon A. R. Oliveira,${ }^{b}$ Geralda F. Lemes, ${ }^{c}$ Wanderson Romão, ${ }^{d, e}$ \\ Boniek G. Vaz, ${ }^{b}$ Sérgio Albuquerque, ${ }^{f}$ Cristiana Gonçalez, ${ }^{f}$ Luciano M. Lião ${ }^{*, b}$ and \\ Maria Teresa F. Bara ${ }^{a}$
}

${ }^{a}$ Faculdade de Farmácia, Universidade Federal de Goiás, Rua 240, s/n, Setor Leste Universitário, 74605-170 Goiânia-GO, Brazil

\author{
${ }^{b}$ Instituto de Química, Universidade Federal de Goiás, Campus Samambaia, 74690-900 Goiânia-GO, Brazil \\ ${ }^{c}$ Universidade Estadual de Goiás, Campus Anápolis de Ciências Exatas e Tecnológicas Henrique Santillo, \\ BR-153, km 98, 75001-970 Anápolis-GO, Brazil
}

${ }^{d}$ Instituto Federal de Educação, Ciência e Tecnologia do Espírito Santo, Campus Vila Velha, Avenida Ministro Salgado Filho, 1000, 29106-010 Vila Velha-ES, Brazil

${ }^{e}$ Laboratório de Petroleômica e Química Forense, Departamento de Química, Universidade Federal do Espírito Santo, Av. Fernando Ferrari, 514, 29075-910 Vitória-ES, Brazil

${ }^{f}$ Faculdade de Ciências Farmacêuticas de Ribeirão Preto, Universidade de São Paulo, Av. do Café s/n, 14040-903 Ribeirão Preto-SP, Brazil

\begin{abstract}
A furanoditerpene-enriched fraction was obtained from the fruits of Pterodon emarginatus and submitted to semipreparative high performance liquid chromatography (HPLC). Two new furanoditerpenes, $6 \alpha, 19 \beta$-diacetoxy-7 $\beta, 14 \beta$-dihydroxyvouacapan and $6 \alpha$-acetoxy$7 \beta, 14 \beta$-dihydroxyvouacapan, in addition to the known compound methyl $6 \alpha$-acetoxy$7 \beta$-hydroxyvouacapan-17 $\beta$-oate were obtained. Compound structures were determined by $1 \mathrm{D}$ and 2D nuclear magnetic resonance (NMR) experiments and electrospray ionization Fourier transform ion cyclotron resonance mass spectrometry (ESI-FTICR-MS). The major compound methyl $6 \alpha$-acetoxy-7 $\beta$-hydroxyvouacapan-17 $\beta$-oate was evaluated against promastigote forms of Leishmania amazonensis and L. braziliensis, presenting the concentration which causes lysis on $50 \%$ of parasites $\mathrm{IC}_{50}<30 \mu \mathrm{g} \mathrm{mL} \mathrm{m}^{-1}$.
\end{abstract}

Keywords: Pterodon, furanoditerpenes, vouacapan, Leishmania

\section{Introduction}

According to the website The Plant List, ${ }^{1}$ Pterodon (Fabaceae) comprises two native Brazilian species, popularly known as "sucupira-branca" or "faveiro": Pterodon abruptus (Moric.) Benth. (synonym: P. apparicioi) and $P$. emarginatus Vogel (synonyms: P. polygalaeflorus, $P$. polygaliflorus and $P$. pubescens). These species are found in the Brazilian Cerrado and their fruits have often been used in popular medicine for their anti-rheumatic, analgesic and anti-inflammatory properties. ${ }^{2}$ Vouacapan furanoditerpenes are constituents of these fruits, and present some pharmacological properties, such as anti-

*e-mail: lucianoliao@ufg.br inflammatory, ${ }^{3}$ antiproliferative against human cancer cells, ${ }^{4}$ antiedematogenic ${ }^{5}$ and antinociceptive activities. ${ }^{6}$

In the present study, two new furanoditerpenes, as well as one that has been previously described in the literature, were obtained from $P$. emarginatus through semi-preparative high performance liquid chromatography (HPLC). Their structures were determined via one and two-dimensional nuclear magnetic resonance (1D and 2D NMR) experiments, electrospray ionization Fourier transform ion cyclotron resonance mass spectrometry (ESI-FTICR-MS), and comparison with data from literature. In addition to the chemical study, compound methyl $6 \alpha$-acetoxy$7 \beta$-hydroxyvouacapan-17 $\beta$-oate was evaluated against promastigote forms of Leishmania amazonensis and L. braziliensis. 


\section{Experimental}

\section{General procedures}

NMR experiments were performed on a Bruker Avance III 11.75 Tesla spectrometer at $25{ }^{\circ} \mathrm{C}$, using a $5 \mathrm{~mm}$ broadband probehead with a z-gradient. Spectra were obtained at $500.13 \mathrm{MHz}$ for ${ }^{1} \mathrm{H}$, using $\mathrm{CDCl}_{3}$ as the solvent and tetramethylsilane (TMS) as the internal standard. Complete signal assignment was also obtained by heteronuclear multiple bond correlation (HMBC) and heteronuclear single quantum correlation (HSQC) experiments, and eventually by ${ }^{13} \mathrm{C}$ analysis. A Model $9.4 \mathrm{~T}$ Solarix mass spectrometer (Bruker Daltonics, Bremen, Germany) was set to operate over a mass range of $\mathrm{m} / \mathrm{z}, 150-2000$. The ESI source conditions were as follows: nebulizer gas pressure: 3 bar; capillary voltage: $3.5 \mathrm{kV}$; transfer capillary temperature: $250{ }^{\circ} \mathrm{C}$. Ions accumulated in the hexapole collision cell in $5 \times 10^{-3} \mathrm{~s}$ were then transported to the analyzer cell (ICR) through the multipole ion guide system (another hexapole). The time-of-flight in the hexapole was $0.5 \mathrm{~ms}$. Each spectrum was acquired by accumulating 200 scans of time-domain transient signals in 4 mega-point time-domain data sets. All mass spectra were externally calibrated using arginine (for ESI+) and sodium salt of trifluoroacetic acid (NaTFA) (for ESI-) solutions $\left(\mathrm{m} / \mathrm{z}\right.$ 200-2000). A resolving power, $\mathrm{m} / \Delta \mathrm{m}_{50 \%}$ ca. 730000 , in which $\Delta \mathrm{m}_{50 \%}$ is the full width at half maximum height, with $m / z$ ca. 400 and mass accuracy of $<1 \mathrm{ppm}$, provided the unambiguous molecular formula assignments for singly charged molecular ions. Mass spectra were acquired and processed using data analysis software (Bruker Daltonics, Bremen, Germany). The MS data was processed and compounds' elemental compositions were determined by measuring $\mathrm{m} / \mathrm{z}$ values. Semi-preparative HPLC was performed using a Shimadzu LC-8A model (Kyoto, Japan), equipped with an SPD-20A UV detector and a Shimadzu C18 column $(250 \times 20 \mathrm{~mm}, 5 \mu \mathrm{m})$. Data processing was performed by LC Solution. All solvents used in chromatographic separations were of HPLC grade (Merck KGaA, Darmstadt, Germany), and analytical grade solvents were used for extraction (Qhemis, Brazil).

\section{Plant materials}

Fruits of P. emarginatus were collected in the Cerrado region of Bela Vista, Goiás State, Brazil. A voucher specimen was authenticated by Prof José Realino de Paula and deposited in the herbarium of Universidade Federal de Goiás (UFG), Brazil, under No. 27,155.

\section{Extraction and isolation}

Oleoresin extraction was performed by mechanical pressing using a continuous mini-press (MPE-40 ECIRTEC, Brazil). The extraction yield was $30 \%$ in weight. Regarding prior purification, $10.06 \mathrm{~g}$ of P. emarginatus fruit oil were extracted with $100 \mathrm{~mL}$ hexane. The insoluble fraction was solubilized in $100 \mathrm{~mL}$ methanol:water $(9: 1, \mathrm{v} / \mathrm{v})$ and submitted to partitioning with $105 \mathrm{~mL}$ of a dichloromethane:hexane $(6.3: 3.7, \mathrm{v} / \mathrm{v})$ mixture. Following agitation, distilled water was added until phase separation was complete ( $45 \mathrm{~mL})$. The dichloromethane:hexane (DHF) fraction was submitted to rotaevaporation at $40{ }^{\circ} \mathrm{C}$ and used to isolate furanoditerpenes.

Approximately $170 \mathrm{mg}$ of DHF was purified by semi-preparative reversed phase (RP)-HPLC under the following column chromatography conditions: Shimadzu C18 column $(250 \times 20 \mathrm{~mm}, 5 \mu \mathrm{m})$, detection wavelength of 190 and $220 \mathrm{~nm}$, injection volume of $1.5 \mathrm{~mL}$, mobile phase of acetonitrile:water $(65: 35, \mathrm{v} / \mathrm{v})$ mixture acidified with $0.05 \%$ acetic acid $(\mathrm{v} / \mathrm{v})$, at a flow rate of $8 \mathrm{~mL} \mathrm{~min}^{-1}$. Three samples were injected and fractions related to the three main chromatographic peaks (retention time ca. 17, 26 and $30 \mathrm{~min}$ ) were collected, concentrated in a rotary evaporator at $40{ }^{\circ} \mathrm{C}$, and freeze-dried (MicroModulyo 115 freeze-dryerThermoFisher Scientific). The major constituents of the three collected fractions had their structures established by NMR and corroborated by mass spectrometry as $6 \alpha, 19 \beta$-diacetoxy-

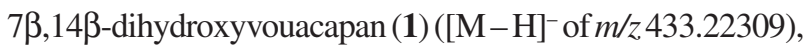
$6 \alpha$-acetoxy-7 $\beta, 14 \beta$-dihydroxyvouacapan (2) $\left([\mathrm{M}+\mathrm{Na}]^{+}\right.$ of $\mathrm{m} / \mathrm{z}$ 399.21415), $6 \alpha$-acetoxy-7 $\beta$-hydroxyvouacapan$17 \beta$-oate (3) $\left([\mathrm{M}-\mathrm{H}]^{-}\right.$of $\mathrm{m} / \mathrm{z}$ 403.21248).

\section{Antileishmanial assay}

Promastigote forms of $L$. amazonensis and $L$. braziliensis were cultivated in M199 (Sigma-Aldrich) supplemented with $10 \%$ bovine fetal serum (Gibco), $0.22 \% \mathrm{NaHCO}_{3}$, and $0.5 \%$ penicillin-streptomycin solution (SigmaAldrich) at $23{ }^{\circ} \mathrm{C}$ for 6 days. Promastigote forms of L. amazonensis and L. braziliensis $\left(10^{6}\right.$ parasites $\left.\mathrm{mL}^{-1}\right)$ were deposited in 96-well microplates and treated with different concentrations of compound $\mathbf{3}\left(8,32\right.$ and $\left.128 \mu \mathrm{g} \mathrm{mL}^{-1}\right)$ for 24 and $72 \mathrm{~h}$.

After treatments, $50 \mu \mathrm{L}$ of tetrazolium dye MTT (2.5 $\mathrm{mg} \mathrm{mL}^{-1}$ ) were added to each well in the plate, which was incubated for $4 \mathrm{~h}$ at $23^{\circ} \mathrm{C}$. Formazan crystals produced by viable cells were solubilized with $50 \mu \mathrm{L}$ per well of SDS $(10 \% \mathrm{~m} / \mathrm{v})$ and plates were incubated at $37^{\circ} \mathrm{C}$ for $60 \mathrm{~min}$. Following incubation, absorbance was measured at $570 \mathrm{~nm}$ using a microplate reader (BioTek, Synergy H1 Hybrid 
Reader). Bioassays were performed in triplicate, with dimethylsulfoxide (DMSO) solution being used in the same concentration that was applied for sample solubilization, as negative control and amphotericin B as reference drug.

The leishmanicidal activity of compound $\mathbf{3}$ was expressed as $\mathrm{IC}_{50}$ values, corresponding to the concentration which causes lysis on $50 \%$ of parasites. These values were calculated by the statistical method of sigmoid concentration-response curve, via GraphPad Prism 5.0.

\section{Results and Discussion}

Vouacapan furanoditerpenes were obtained from an enriched sample (DHF) by semipreparative RP-HPLC. Fractions amounting to shaded peaks 1, 2, and 3-4 (Figure 1) were collected from three injections, which produced white solids following concentration and freezedrying steps. Fractions from shaded areas 3 and 4 (Figure 1) were grouped, hence yielding $30.0 \mathrm{mg}$ of a pure compound. Fractions 1 and 2 yielded $7.5 \mathrm{mg}$ each. As may be observed in the chromatogram and confirmed by ${ }^{1} \mathrm{H}$ NMR spectra, fractions 1 and 2 contain impurities due to the coelution of substances whose retention times are close to those of the major compounds (Figure 1, particularly at $190 \mathrm{~nm}$ ).

The structures of the new compounds $6 \alpha, 19 \beta$-diacetoxy$7 \beta, 14 \beta$-dihydroxyvouacapan (1) and $6 \alpha$-acetoxy$7 \beta, 14 \beta$-dihydroxyvouacapan ( 2 ) were elucidated by NMR experiments and confirmed by MS and data from literature (Figure 2) ${ }^{7,8}$ These experiments were also used to identify compound $\mathbf{3}$ as methyl $6 \alpha$-acetoxy-7 $\beta$-hydroxyvouacapan$17 \beta$-oate, previously identified in P. apparicioi and P. emarginatus. ${ }^{9-11}$

The ${ }^{1} \mathrm{H}$ NMR spectrum for compound 1 showed hydrogen furans at $\delta_{\mathrm{H}} 6.42\left(1 \mathrm{H}, \mathrm{d}, J 1.9 \mathrm{~Hz}, \mathrm{H}_{15}\right)$ and $\delta_{\mathrm{H}} 7.26$ $\left(1 \mathrm{H}, \mathrm{d}, J 1.9 \mathrm{~Hz}, \mathrm{H}_{16}\right)$. Two acetyl groups were assigned by the signals at $\delta_{\mathrm{H}} 5.36\left(1 \mathrm{H}, \mathrm{dd}, J 11.8\right.$ and $\left.9.2 \mathrm{~Hz}, \mathrm{H}_{6}\right)$,

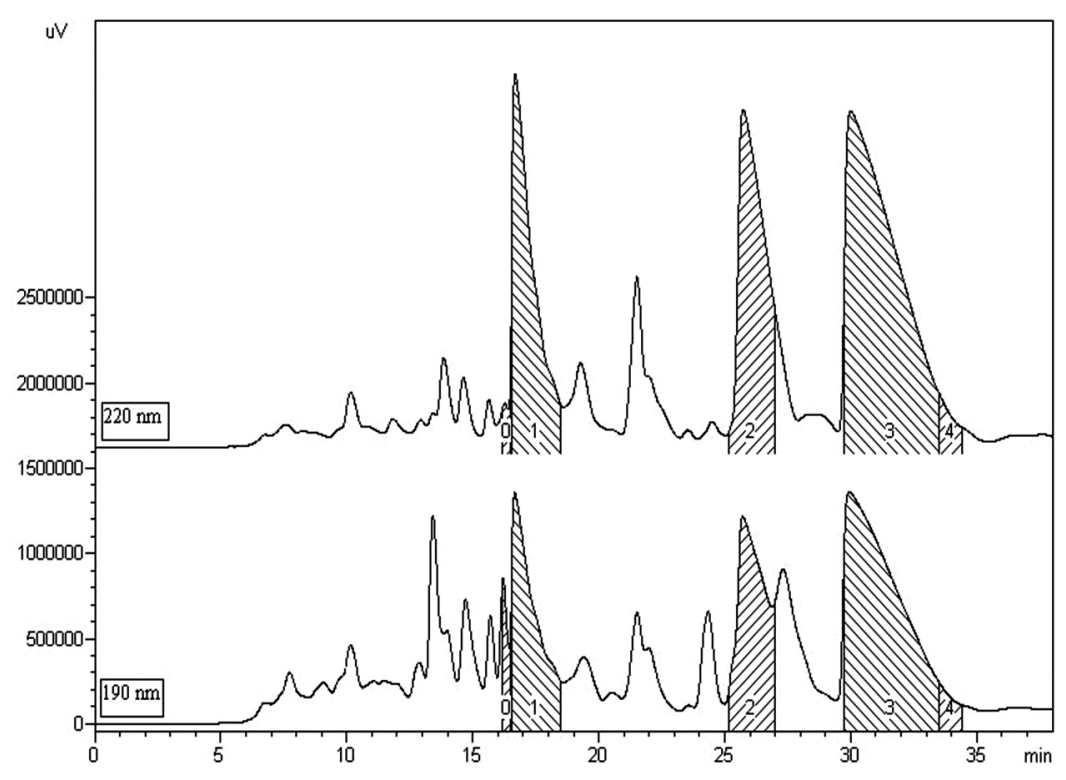

Figure 1. Chromatographic profile of the enriched fraction of the P. emarginatus oleoresin, obtained via semi-preparative HPLC at $190 \mathrm{and} 220 \mathrm{~nm}$. Shaded areas 1,2, and 3-4 correspond to the collected fractions. The chromatogram at $220 \mathrm{~nm}$ is displaced on the y-axis for a clearer presentation.

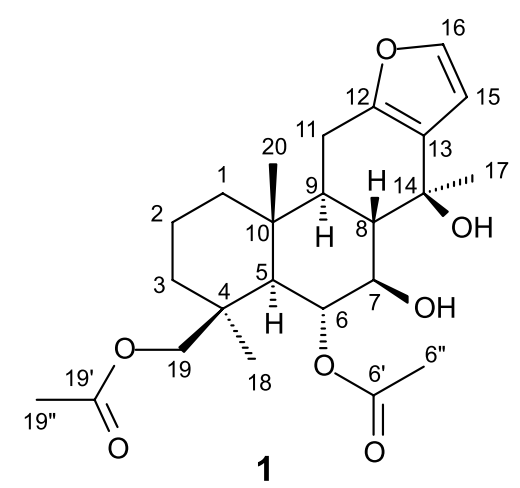

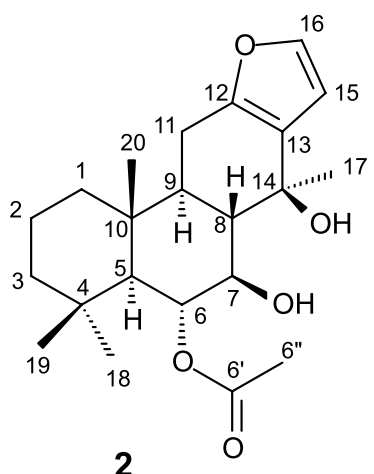

2<smiles>COC(=O)[C@H]1c2ccoc2C[C@H]2[C@@H]1[C@H](O)[C@H](OC(C)=O)[C@@H]1C(C)(C)CCC[C@@]21C</smiles>

Figure 2. Structure of vouacapan diterpenes $\mathbf{1}, \mathbf{2}$ and $\mathbf{3}$. 
$\delta_{\mathrm{H}} 4.12(1 \mathrm{H}, \mathrm{d}, J 11.3 \mathrm{~Hz}, \mathrm{H}-19 \mathrm{a}), \delta_{\mathrm{H}} 4.22(1 \mathrm{H}, \mathrm{d}, J 11.3 \mathrm{~Hz}$, $\mathrm{H}-19 \mathrm{~b}), \delta_{\mathrm{H}} 2.19\left(3 \mathrm{H}, \mathrm{s}, \mathrm{H}_{6^{\prime \prime}}\right)$, and $\delta_{\mathrm{H}} 2.05\left(3 \mathrm{H}, \mathrm{s}, \mathrm{H}_{19^{\prime}}\right)$. Three methyl groups were observed at $\delta_{\mathrm{H}} 1.46\left(3 \mathrm{H}, \mathrm{s}, \mathrm{H}_{17}\right), 1.14$ $\left(3 \mathrm{H}, \mathrm{s}, \mathrm{H}_{18}\right)$ and $1.05\left(3 \mathrm{H}, \mathrm{s}, \mathrm{H}_{20}\right)$.

The ${ }^{13} \mathrm{C}$ NMR associated with cross peaks observed in HSQC and HMBC experiments corroborated typical signals for vouacapan's furan ring at $\delta_{\mathrm{C}} 148.2,141.9,123.9$ and 107.2. Two acetoxy and three carbinolic groups were also observed at $\delta_{\mathrm{C}} 172.6,171.2,77.5,75.8$ and 72.6.

These data are very similar to that presented for known compound 3 (Table 1), except for the replacement of carbomethoxy and hydrogen groups at $\mathrm{C}_{14}$ for hydroxyl and methyl groups. Replacement of hydrogen by one acetoxy group at $\mathrm{C}_{19}$ was also observed. The hydroxyl group at $\mathrm{C}_{14}$ was confirmed by cross peaks between hydrogens $\mathrm{H}_{7}$, $\mathrm{H}_{8}$ and $\mathrm{H}_{15}\left(\delta_{\mathrm{H}} 3.81,2.02\right.$ and 6.42) with $\mathrm{C}_{14}$ at $\delta_{\mathrm{C}} 72.6$ in the HMBC experiment. The doublets at $\delta_{\mathrm{H}} 4.12$ and 4.22 $(J 11.3 \mathrm{~Hz})$ as well as the cross peak between $\mathrm{H}_{19}$ and carbonyl at $\delta_{\mathrm{C}} 171.2$ confirmed the position of this new acetoxy group. Cross peaks between these signals and carbons $\mathrm{C}_{4}, \mathrm{C}_{5}$ and $\mathrm{C}_{18}\left(\delta_{\mathrm{C}} 38.7,55.0\right.$ and 30.6), observed in the HMBC experiment, suggested that the acetoxy group is attached to $\mathrm{C}_{19}$. The $\mathrm{C}_{4}$ and $\mathrm{C}_{14}$ stereochemistry were evaluated by nuclear Overhauser effect (NOE) experiments (Figures $\mathrm{S} 6$ and S7). The observed NOE between $\mathrm{H}_{5}, \mathrm{H}_{7}$ and Me-18 corroborate acetoxy group on $\mathrm{C}_{19}$. On the other hand, the NOE between Me-17, $\mathrm{H}_{7}$ and $\mathrm{H}_{15}$ confirmed hydroxyl group on $\beta$ position. No NOE was observed between $\mathrm{H}_{8}$ and Me-17. The $\mathrm{C}_{14}$ stereochemistry in is agreement with that proposed for two furanoditerpenes voucapanes containing methyl and hydroxyl groups attached on $\mathrm{C}_{14}{ }^{12}$ The proposed structure is in agreement with $6 \alpha, 19 \beta$-diacetoxy-7 $\beta, 14 \beta$-dihydroxyvouacapan (1).

Compounds $\mathbf{1}$ and $\mathbf{2}$ show very similar NMR spectra (Table 1). The most significant difference was due to the absence of the acetoxy group attached to $\mathrm{C}_{19}$. One methyl group is attached in this position, according to the signal at $\delta_{\mathrm{H}} 1.06(\mathrm{~s})$. Basing on this data, the $6 \alpha$-acetoxy$7 \beta, 14 \beta$-dihydroxyvouacapan structure was proposed for compound 2.

Table 1. ${ }^{1} \mathrm{H}$ and ${ }^{13} \mathrm{C}$ NMR spectra data for diterpenes $\mathbf{1}, \mathbf{2}$ and $\mathbf{3}$, isolated from the fruit oil of P. emarginatus $\left(500 \mathrm{MHz}, \mathrm{CDCl}_{3}\right)$

\begin{tabular}{|c|c|c|c|c|c|c|}
\hline \multirow{2}{*}{$\mathrm{H} / \mathrm{C}$} & \multicolumn{2}{|l|}{1} & \multicolumn{2}{|l|}{2} & \multicolumn{2}{|l|}{3} \\
\hline & $\delta^{1} \mathrm{H} / \mathrm{ppm}$ (mult., $\left.J / \mathrm{Hz}\right)$ & $\delta{ }^{13} \mathrm{C} / \mathrm{ppm}$ & $\delta^{1} \mathrm{H} / \mathrm{ppm}$ (mult., $\left.J / \mathrm{Hz}\right)$ & $\delta^{13} \mathrm{C} / \mathrm{ppm}$ & $\delta^{1} \mathrm{H} / \mathrm{ppm}$ (mult., $\left.J / \mathrm{Hz}\right)$ & $\delta{ }^{13} \mathrm{C} / \mathrm{ppm}$ \\
\hline 1 & $1.7-1.6(\mathrm{~m}) ; 1.2-1.1(\mathrm{~m})$ & 38.4 & $1.7-1.6(\mathrm{~m}) ; 1.0-0.9(\mathrm{~m})$ & 39.4 & $1.7-1.6(\mathrm{~m}) ; 1.0-0.9(\mathrm{~m})$ & 39.5 \\
\hline 2 & $1.6-1.4(\mathrm{~m})$ & 18.0 & $1.6-1.4(\mathrm{~m})$ & 18.1 & $1.6-1.4(\mathrm{~m})$ & 18.5 \\
\hline 3 & $1.8-1.7(\mathrm{~m}) ; 1.1-1.0(\mathrm{~m})$ & 39.5 & $1.2-1.1(\mathrm{~m}) ; 1.4-1.3(\mathrm{~m})$ & 43.3 & $1.2-1.1(\mathrm{~m}) ; 1.4-1.3(\mathrm{~m})$ & 43.7 \\
\hline 4 & - & 38.7 & - & 32.9 & - & 33.2 \\
\hline 5 & $1.46(\mathrm{~d}, 11.8)$ & 55.0 & $1.29(\mathrm{~d}, 11.6)$ & 54.3 & $1.28(\mathrm{~d}, 11.5)$ & 55.0 \\
\hline 6 & $5.36(\mathrm{dd}, 11.8,9.2)$ & 75.8 & $5.33(\mathrm{dd}, 11.6,9.2)$ & 75.8 & $5.21(\mathrm{dd}, 11.5,9.4)$ & 75.7 \\
\hline 7 & $3.81(\mathrm{dd}, 10.6,9.2)$ & 77.5 & $3.85(\mathrm{dd}, 10.6,9.2)$ & 76.7 & $3.31(\mathrm{dd}, 10.6,9.4)$ & 81.4 \\
\hline 8 & $2.02(\mathrm{dd}, 12.5,10.6)$ & 49.5 & $2.04(\mathrm{dd}, 12.5,10.6)$ & 49.6 & $2.37(\mathrm{ddd}, 11.7,10.6,9.1)$ & 42.7 \\
\hline 9 & $1.5-1.4(\mathrm{~m})$ & 46.9 & $1.5-1.4(\mathrm{~m})$ & 46.7 & $1.45(\mathrm{ddd}, 11.7,5.6,4.9)$ & 48.2 \\
\hline 10 & - & 37.0 & - & 38.6 & - & 38.6 \\
\hline 11 & $\begin{array}{c}2.62(\mathrm{dd}, 16.6,6.6) \\
2.45(\mathrm{dd}, 16.6,10.5)\end{array}$ & 22.5 & $\begin{array}{c}2.61(\mathrm{dd}, 16.6,6.5) \\
2.44(\mathrm{dd}, 16.6,10.7)\end{array}$ & 22.2 & $\begin{array}{l}2.64(\mathrm{dd}, 16.1,5.6) \\
2.41(\mathrm{dd}, 16.1,4.9)\end{array}$ & 22.2 \\
\hline 12 & - & 148.2 & - & 148.4 & - & 150.5 \\
\hline 13 & - & 123.9 & - & 123.7 & - & 113.6 \\
\hline 14 & - & 72.6 & - & 72.6 & $3.38(\mathrm{~d}, 9.1)$ & 46.6 \\
\hline 15 & $6.42(\mathrm{~d}, 1.9)$ & 107.2 & $6.42(\mathrm{~d}, 1.9)$ & 107.0 & $6.14(\mathrm{~d}, 1.7)$ & 108.6 \\
\hline 16 & $7.26(\mathrm{~d}, 1.9)$ & 141.9 & $7.26(\mathrm{~d}, 1.9)$ & 141.6 & $7.21(\mathrm{~d}, 1.7)$ & 141.6 \\
\hline 17 & $1.46(\mathrm{~s})$ & 25.9 & $1.47(\mathrm{~s})$ & 25.6 & - & 175.6 \\
\hline 18 & $1.14(\mathrm{~s})$ & 30.6 & $1.06(\mathrm{~s})$ & 36.1 & $1.00(\mathrm{~s})$ & 36.5 \\
\hline 19 & $\begin{array}{l}4.22(\mathrm{~d}, 11.3) \\
4.12(\mathrm{~d}, 11.3)\end{array}$ & 67.0 & $0.96(\mathrm{~s})$ & 22.4 & $0.92(\mathrm{~s})$ & 22.7 \\
\hline 20 & $1.05(\mathrm{~s})$ & 16.3 & $1.07(\mathrm{~s})$ & 15.6 & $1.05(\mathrm{~s})$ & 15.7 \\
\hline 6 & - & 172.6 & - & 172.0 & - & 172.1 \\
\hline 6" & $2.19(\mathrm{~s})$ & 21.9 & $2.16(\mathrm{~s})$ & 21.7 & $2.09(\mathrm{~s})$ & 22.6 \\
\hline $19^{\prime}$ & - & 171.2 & - & - & - & - \\
\hline $19 "$ & $2.05(\mathrm{~s})$ & 20.9 & - & - & - & - \\
\hline OMe-17 & - & - & - & - & $3.70(\mathrm{~s})$ & 52.5 \\
\hline
\end{tabular}

${ }^{1} \mathrm{H}$ and ${ }^{13} \mathrm{C}$ NMR assignments are based on ${ }^{1} \mathrm{H}$ and ${ }^{13} \mathrm{C}$ spectra and on ${ }^{1} \mathrm{H}-{ }^{13} \mathrm{C}$ HSQC and HMBC contour maps; s: singlet; m: multiplet; d: doublet; dd: double doublets; ddd: double double doublets. 
Figure 3 shows the ESI(-)-FTICR mass spectrum of these three diterpenes $(\mathbf{1}, \mathbf{2}$ and $\mathbf{3})$. Diterpene $\mathbf{1}$ was detected in deprotonated form $[\mathrm{M}-\mathrm{H}]^{-}$of $m / z 433.22309$ with an error of $0.20 \mathrm{ppm}$. Diterpene 2 was detected as sodium adduct $[\mathrm{M}+\mathrm{Na}]^{+}$of $\mathrm{m} / z 399.21415$ with an error of $0.11 \mathrm{ppm}$. Diterpene 3 was detected in the negative ion mode in deprotonated form $[\mathrm{M}-\mathrm{H}]^{-}$of $\mathrm{m} / \mathrm{z} 403.21248$ with an error of $0.13 \mathrm{ppm}$. In all cases, the ultra-high resolution mass spectrum provides the exact mass with an error lower than $1 \mathrm{ppm}$.

The antiparasitic activity of furanoditerpene $\mathbf{3}$ was assessed in vitro against promastigotes of $L$. amazonensis and L. braziliensis, resulting in significant leishmanicidal activity (Table 2). ${ }^{13}$

Diterpenes rank among the classes of secondary metabolites with promising leishmanicidal activity. ${ }^{14}$ Leishmaniasis is regarded as a neglected disease, and this is the first study to report on assays carried out with furanoditerpenes vouacapan isolated from fruits of the Pterodon genus. Further studies on the pharmacological potential of Pterodon furanoditerpenes should be encouraged, as they contribute to the development of drugs for neglected diseases and favor the preservation of Cerrado.

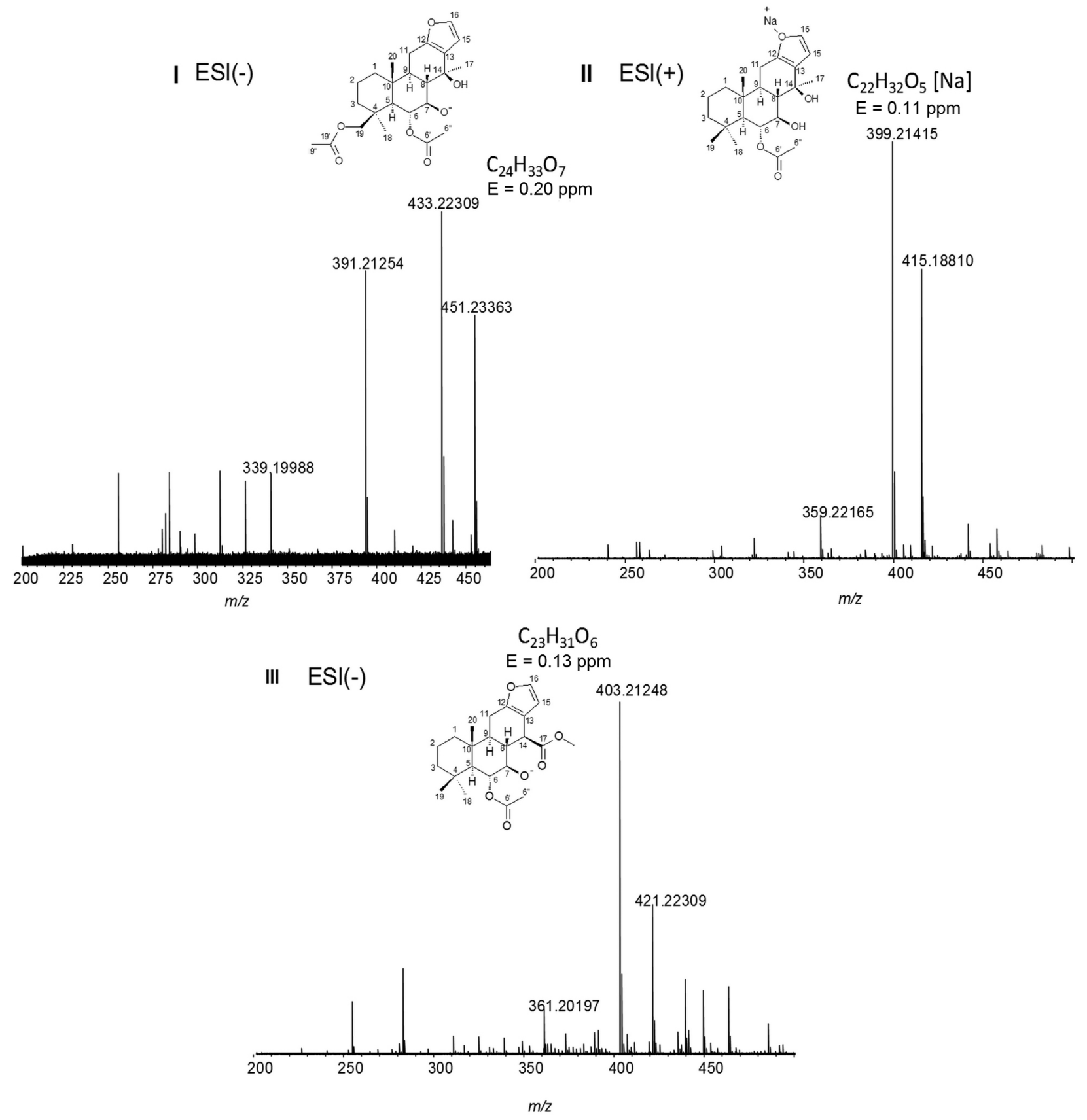

Figure 3. ESI-FTICR mass spectrum of vouacapan diterpenes 1, 2 and $\mathbf{3}$. 
Table 2. Antiparasitic activities of compound $\mathbf{3}$ and amphotericin B

\begin{tabular}{lcccc}
\hline \multirow{2}{*}{ Compound } & \multicolumn{4}{c}{$\mathrm{IC}_{50} /\left(\mu \mathrm{g} \mathrm{mL}^{-1}\right)$} \\
\cline { 2 - 5 } & \multicolumn{2}{c}{ Leishmania amazonensis } & \multicolumn{2}{c}{ Leishmania braziliensis } \\
\cline { 2 - 5 } & $24 \mathrm{~h}$ & $24 \mathrm{~h}$ & $72 \mathrm{~h}$ \\
\hline $\mathbf{3}$ & $25.47 \pm 1.01$ & $20.12 \pm 0.76$ & $26.12 \pm 0.18$ & $17.94 \pm 1.94$ \\
\hline
\end{tabular}

$\mathrm{IC}_{50}$ : half-maximal inhibitory concentration; data expressed as mean of triplicates \pm standard deviation.

\section{Conclusions}

The phytochemical study of P. emarginatus fruits has led to the isolation and elucidation of two new furanoditerpenes, $6 \alpha, 19 \beta$-diacetoxy-7 $\beta, 14 \beta$-dihydroxyvouacapan (1) and $6 \alpha$-acetoxy-7 $\beta, 14 \beta$-dihydroxyvouacapan (2), in addition to the known compound methyl $6 \alpha$-acetoxy$7 \beta$-hydroxyvouacapan-17 $\beta$-oate (3). Compound methyl $6 \alpha$-acetoxy-7 $\beta$-hydroxyvouacapan-17 $\beta$-oate (3) was found as a promising leishmanicidal agent.

\section{Supplementary Information}

Supplementary data are available free of charge at http://jbcs.sbq.org.br as PDF file.

\section{Acknowledgments}

The authors are grateful to Conselho Nacional de Desenvolvimento Científico e Tecnológico (CNPq), Coordenação de Aperfeiçoamento de Pessoal de Nível Superior (CAPES), Fundação de Amparo à Pesquisa do Estado de Goiás (FAPEG), and Financiadora de Estudos e Projetos (FINEP) for their financial support.

\section{References}

1. www.theplantlist.org/tpl1.1/search?q=pterodon, accessed in February 2017

2. Hansen, D.; Haraguchi, M.; Alonso, A.; Braz. J. Pharm. Sci. 2010, 46, 607.

3. Galceran, C. B.; Sertie, J. A. A.; Lima, C. S.; Carvalho, J. C. T.; Inflammopharmacology 2011, 19, 139.

4. Euzébio, F. P. G.; Santos, F. J. L.; Veloso, D. P.; Ruiz, A. L. T. G.; Carvalho, J. E.; Alves, D. L. F.; Fátima, A.; Bioorg. Chem. 2009, 37, 96.
5. Nucci, C.; Martins, L. M.; Stramosk, J.; Brethanha, L. C.; Pizzolatti, M. G.; Santos, A. R. S.; Martins, D. F.; J. Ethnopharmacol. 2012, 143, 170.

6. Spindola, H. M.; Servat, L.; Denny, C.; Rodrigues, R. A. F.; Eberlin, M. N.; Cabral, E.; Souza, I. M. O.; Tamashiro, J. Y.; Carvalho, J. E.; Foglio, M. A.; BMC Pharmacol. 2010, 10, 1.

7. Spindola, H. M.; Carvalho, J. E.; Ruiz, A. L. T. G.; Rodrigues, R. A. F.; Denny, C.; Sousa, I. M. O.; Tamashiro, J. Y.; Foglio, M. A.; J. Braz. Chem. Soc. 2009, 20, 569.

8. Hurtado, M. G.; Esquivel, F. E. A.; García, G. R.; Pacheco, M. M. M.; Madrigal, R. M. E.; Bolanõs, T. P.; Hernández, J. L. S.; Gutiérrez, H. A. G.; Rojas, C. M. C. G.; Nathan, P. J.; Rio, R. E.; Phytochemistry 2013, 96, 397.

9. Pereira, M. F.; Martino, T.; Dalmau, S. R.; Albano, R. M.; Férézou, J. P.; Costa, S. S.; Coelho, M. G. P.; Sabino, K. C. C.; Oncol. Rep. 2011, 25, 215.

10. Servat, L.; Spindola, H. M.; Rodrigues, R. A. F.; Sousa, I. M. O.; Ruiz, A. L. T. G.; Carvalho, J. E.; Foglio, M. A.; J. Braz. Chem. Soc. 2012, 23, 1244.

11. Fascio, M.; Mors, W. B.; Gilbert, B.; Mahajan, J. R.; Monteiro, M. B.; Filho, D. D. S.; Vichnewski, W.; Phytochemistry 1976, $15,201$.

12. Demuner, A. J.; Barbosa, L. C. A.; Veloso, D. P.; Alves, D. L. F.; Howarth, O. W.; J. Nat. Prod. 1996, 59, 770.

13. Carmona, D. B. D.; Erosa, F. E.; Sosa, K. G.; Pinell, G. R.; Yapu, D. G.; Bacaab, M. J. C.; Puc, R. E. M.; Veitch, N. C.; Turba, A. G.; Rodríguez, L. P.; J. Braz. Chem. Soc. 2011, 22, 1279.

14. Singh, N.; Mishra, B.; Bajpai, S.; Singh, R. K.; Tiwari, V. K.; Bioorg. Med. Chem. 2014, 22, 18.

Submitted: October 24, 2016 Published online: February 15, 2017 